\title{
DESIGN AND SYNTHESIS OF A PIPERAZINE DERIVATIVE AS A HIGH AFFINITY $5-\mathrm{HT}_{\text {IA }}$ RECEPTOR LIGAND
}

\author{
Mohamed A. El-Bermawy \\ Department of OTg. Chemistry, Faculty of Pfarmacy, \\ University of Zagazig, Egypt.
}

\begin{abstract}
Serotonin (5-HT) 1A receptors have been shown to have physiological, biochemical pharmacological and clinical values. The piperazino derivative 1 was rationally designed as a bulky, lipophilic N4-substituted arylpiperazine. Radioligand binding assay of 1 at $5-\mathrm{HT}_{1} \mathrm{~A}$ receptors indicates that it binds at these receptors with higher affinity than the famous $5-\mathrm{HT}_{1 \mathrm{~A}}$ ligand, buspirone $\left(K_{i}=15 n M\right)$. Buspirone is currentiy used to treat anxiety.
\end{abstract}

\section{INTRODUCTION}

The history of serotonin 2 began sixty years ago when it was discovered in the intestine and was then called enteramine ${ }^{(1)}$. In 1947 , serotonin was characterized as a vasoconstrictor substance in the serum and was proven to be 5-hydroxytryptamine $2(5-\mathrm{HT})^{(2)}$. About ten years later, Gaddum and Picarelli proposed two types of tryptamine receptors in guinea pig ileum ${ }^{(3)}$. The first type was blocked by dibenzyline (phenoxybenzamine) and called D receptors. The second type was antagonized by morplinine and called $M$ receptors ${ }^{(3)}$. In 1979, Peroutka and Snyder proposed two distinct types of serotonin receptors in the central nervous system ${ }^{(4)}$. Their classification was based on the radioligand binding technique. One type was called $5-\mathrm{HT}_{1}$ receptors and was labeled by $\left[{ }^{3} \mathrm{H}\right]-5-\mathrm{HT}$. The second type was labeled by the D-2 neuroleptic, $\left[{ }^{3} \mathrm{H}\right]$-spiperone 3 and called $5-\mathrm{HT}_{2}$ receptors ${ }^{(4)}$. Additional studies revealed 
that 3 showed biphasic effect on the $5-\mathrm{HT}_{1}$ receptors, i.e. showed higher affinity for a binding site and lower affinity for another site. The two binding sites were called $5-\mathrm{HT}_{1 \mathrm{~A}}$ and $5-\mathrm{HT}_{1 \mathrm{~B}}$, respectively ${ }^{(5)}$. Recent studies suggested the existence of other kinds of $5-\mathrm{HT}_{1}$ receptors such as $5-\mathrm{HT}_{1 \mathrm{C}}, 5-\mathrm{HT}_{1 \mathrm{D}(\alpha, \beta)}, 5-\mathrm{HT}_{1 \mathrm{E}}, 5-\mathrm{HT}_{1 \mathrm{~S}}, 5-\mathrm{HT}_{1 \mathrm{P}}$ and $5-\mathrm{HT}_{1 \mathrm{R}}{ }^{(6)}$.

In addition to $5-\mathrm{HT}_{1}$ and $5-\mathrm{HT}_{2}$ receptors, $5-\mathrm{HT}_{3}$ receptors were discovered. These receptors were suggested to be the Gaddum and Picarelli $M$ receptors ${ }^{(7)}$. Additional classes of 5 -HT receptors have been also suggested ${ }^{(6-8)}$.

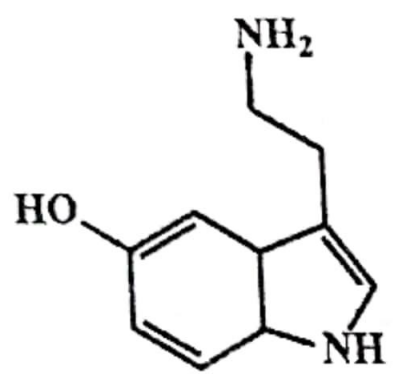

$\stackrel{2}{\sim}$

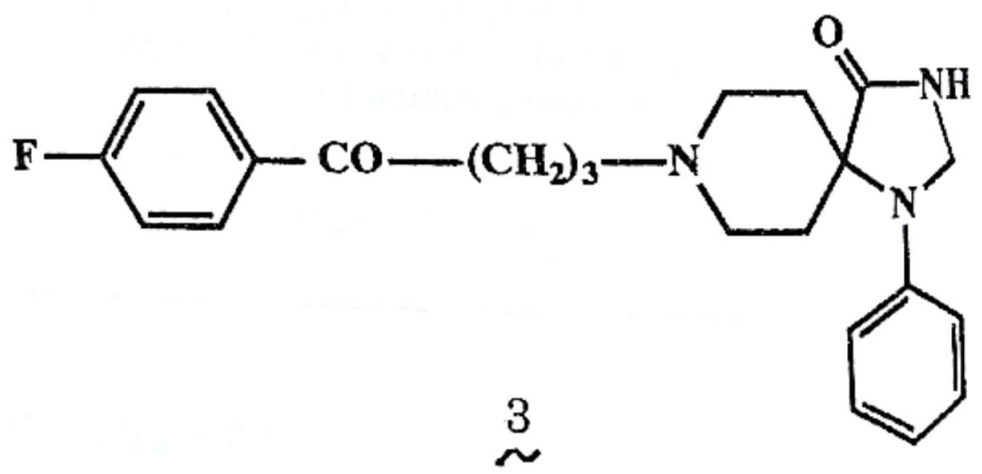

From the various kinds of 5 - $\mathrm{HT}$ receptors, $5-\mathrm{HT}_{1 \mathrm{~A}}$ receptors have received the most attention. This kind plays an important role in the modulation of numerous biological functions such as cardiovascular functions, food intake, temperature, mood, sexual activity and hormonal activities. Various $5-\mathrm{HT}_{\mathrm{IA}}$ ligands have been shown to be useful in many disease states such as anxiety, depression, migraine and
nociception ${ }^{(9-11)}$.

Several classes of ligands were tested for 5 thT classes, arylpiperazines have been shown to possess affinity for $5-\mathrm{HT}_{1} \mathrm{~A}$ receptors ${ }^{(12-14)}$. There was a previous to possess affinity for $5-\mathrm{HT}_{1 \mathrm{~A}}$ 
bind at $5-\mathrm{H}^{\prime} \mathrm{T}_{1 \mathrm{~B}}$ receptors more than at $5-\mathrm{HT}_{1 \mathrm{~A}}$ receptors. Later investigations showed that substitution on the $\mathrm{N}_{4}$ of the piperazine ring provide compounds with modest affinity and selectivity for $5-\mathrm{HT}_{1 \mathrm{~A}}$ receptors ${ }^{(13)}$. Recent studies indicated that increasing the carbon chain (four carbons are optimum length) results in increasing the affinity for 5 - $\mathrm{HT}_{1 \mathrm{~A}}$ receptor sites. Various amido derivatives of 2-methoxyphenylpiperazines bind at these receptors with $\mathrm{K}_{\mathrm{i}}$ in the nanomolar range. The highest affinity ligands were the amides containing branched, bulky and hydrophobic substituents ${ }^{(14,15)}$.

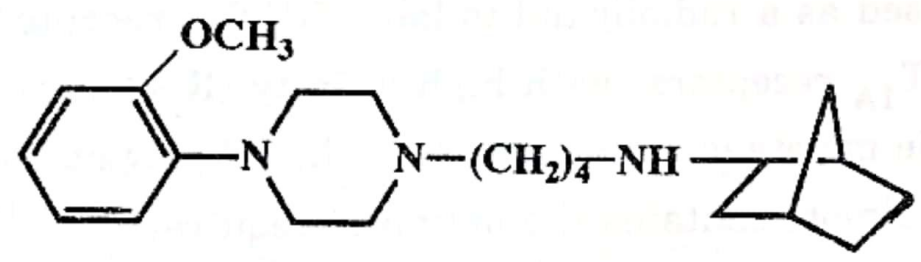

1

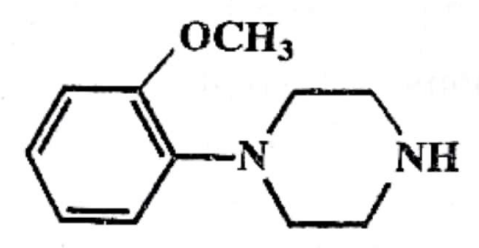

4<smiles>O=C1c2ccccc2C(=O)N1CCBr</smiles>

5

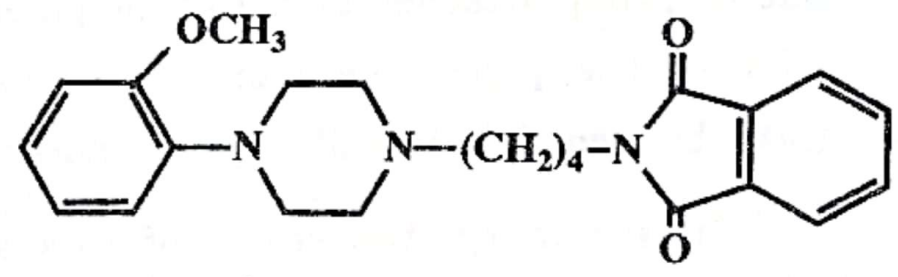

6
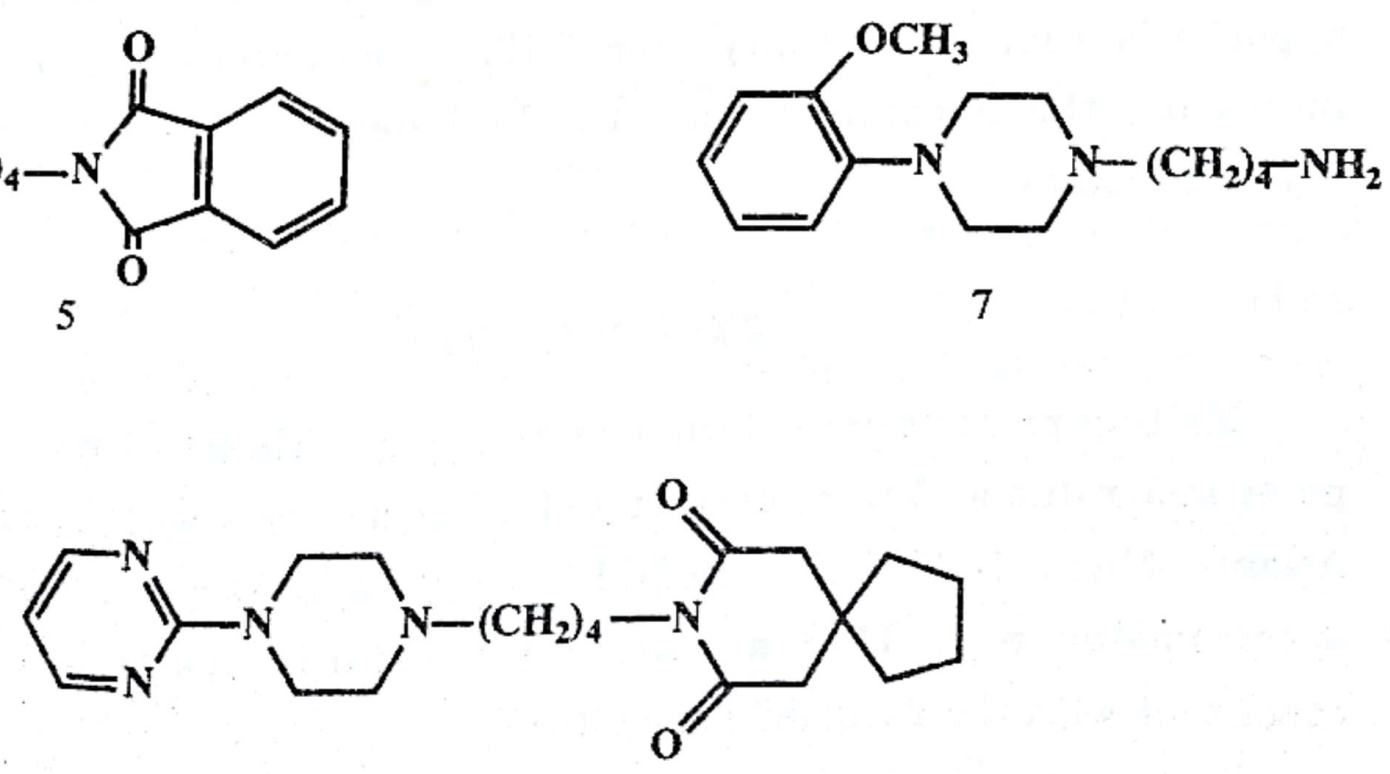

Buspirone 
To further investigate structure affinity relationship (SAFIR), the target ligand 1 was rationally designed and synthesized. It contains a branched, lipophilic and bulky group (the norbornyl moiety) directly attached to an NH not to an amide.

\section{RESULTS AND DISCUSSION}

Radioligand binding studies ${ }^{(16)}$ were performed by using Sprague-Dawley rats. $\left[{ }^{3} \mathrm{H}\right]-8$-hydroxy-n-dipropylaminotetralin $(8-0 \mathrm{H}$ DPAT) was used as a radioligand to label $5-\mathrm{HT}_{1 \mathrm{~A}}$ receptors. Compound 1 binds at $5-\mathrm{HT}_{1 \mathrm{~A}}$ receptors with high affinity $\left(\mathrm{K}_{\mathrm{i}}=4 \mathrm{~nm}\right)$. This indicates that the amide moiety is not essential for the affinity at $5-\mathrm{HT}_{1 \mathrm{~A}}$ receptors. Compound 1 almost contains the optimum requirements ${ }^{(16-18)}$ for $5-\mathrm{HT}_{1}$ receptor ligands which are: (i) methoxy group at the 2 position of the phenyl group attached to $\mathrm{N}-1$ of the piperazine ring (ii), the basic nitrogen (N-4 of the piperazine moiety), (iii) four carbons attached to N-4 and (iv) a branched, bulky-alkyl group, norbornyl).

In summary, the result of this study is in agreement with the previous SAFIR and molecular modeling studies. It supports the hypothesis that the affinity for $5-\mathrm{HT}_{1 \mathrm{~A}}$ receptors enhances with

\section{EXPERIMENTAL}

Melting points were determined by using a Thomas-Hoover melting point apparatus and were uncorrected. Microanalysis were conducted by Atlantic Microlab, USA. Proton NMR spectra were performed on GE-300 spectrometer with TMS as internal standard. Spectral data were consistent with the assigned structures. 


\section{1-2(-Methoxyphenyl)-4-[4-(2-phthalimido)butyl] piperazine 6 :}

This compound was prepared as previously reported ${ }^{(15)}$ with slight modification. $\mathrm{N}$-(4-Bromobutyl)phthalimide 5 (6 g, $0.021 \mathrm{~mol})$ in $\mathrm{CH}_{3} \mathrm{CN}(20$ $\mathrm{mL}$ ) was added to a mixture of 1-(2-methoxyphenyl)piperazine $\mathrm{HCl}(4.87 \mathrm{~g}$, $0.021 \mathrm{~mol}), \mathrm{K}_{2} \mathrm{CO}_{3}(6 \mathrm{~g}, 0.034 \mathrm{~mol})$, and $\mathrm{KI}(10 \mathrm{mg}, 0.047 \mathrm{~mol})$ in $\mathrm{CH}_{3} \mathrm{CN}$ $(20 \mathrm{~mL})$. The reaction mixture was heated under reflux for $24 \mathrm{~h}$ and filtered while hot. The filtrate was evaporated under reduced pressure. The residue was recrystallized from absolute EtOH to afford $7.12 \mathrm{~g}(85 \%)$ of 6, $\mathrm{mp} 80-81^{\circ} \mathrm{C}$ as in literature ${ }^{(15)}$.

\section{4-(4-Aminobutyl)-1-(2-methoxyphenyl)piperazine 7 :}

This compound was prepared from 6 by Gabriel synthesis ${ }^{(16)}$.

\section{1-(2-methoxyphenyl)-4-[4-(norbornylamino) butyl] piperazine fumarate 1:}

The amine 7 (200 $\mathrm{mg}, 0.76 \mathrm{mmol})$ was dissolved in absolute EtOH $(25 \mathrm{ml})$ and mixed with norcamphor $(210 \mathrm{mg}, 1.91 \mathrm{mmol})$ and $10 \% \mathrm{Pd} / \mathrm{C}$ $(70 \mathrm{mg}$ ). The mixture was hydrogenated at $45 \mathrm{psi}$ for $18 \mathrm{~h}$ then filtered over celite pad. The solvent was evaporated under reduced pressure. The resulting residue was dissolved in anhydrous $\mathrm{Et}_{2} \mathrm{O}(10 \mathrm{~mL})$. The fumarate salt was formed by the slow addition of ethereal fumaric acid. The resulting solid was collected by filtration and recrystallized from a mixture of absolute EtOH and anhydrous $\mathrm{Et}_{2} \mathrm{O}$ to afford $79 \mathrm{mg}(58 \%)$ of the title compound as white crystals, mp: $154-156^{\circ} \mathrm{C}$. Anal. $\left(\mathrm{C}_{22} \mathrm{H}_{35} \mathrm{~N}_{3} \mathrm{O}\right.$. Fumarate monohydrate) $\mathrm{C}, 63.52 ; \mathrm{H}, 8.41 ; \mathrm{N}, 8.55$. Found $\mathrm{C}, 63.39 ; \mathrm{H}, 8.02$; $\mathrm{N}, 8.33:{ }^{1} \mathrm{HNMR}$ (DMSO-d $\mathrm{d}_{6} \delta: 1.01-1.7\left(\mathrm{~m}, 8 \mathrm{H}, \mathrm{CH}_{2}\right), 2.2-2.49(\mathrm{~m}, 8 \mathrm{H}$, $\mathrm{CH}_{2}$ ), $3.75\left(\mathrm{~S}, 3 \mathrm{H}, \mathrm{OCH}_{3}\right), 6.83-6.95(\mathrm{~m}, 4 \mathrm{H}, \mathrm{ArH})$. 


\section{A. El-Bermawy}

Radioligand binding studies ${ }^{(17)}$ :

The radioligand binding assay was performed in the laboratory of professor Milt Teitler, Department of Pharmacology, Albany Medical College, USA. Sprague-Dawley rats $(\approx 220 \mathrm{~g})$ were used. Their brains were isolated after decapitation and placed in ice-cold saline. The tissues were homogenized in 30 volumes of ice-cold buffer containing $50 \mathrm{mM}$ tris- $\mathrm{HCl}$, $0.5 \mathrm{mM} \mathrm{Na}_{2}$ EDTA, and $10 \mathrm{mM} \mathrm{MgSO}_{4}$. The homogenized tissues were centrifuged at $30,000 \mathrm{~g}$ for $15 \mathrm{~min}$. The formed pellet was washed and resuspended. The $5-\mathrm{HT}_{1 \mathrm{~A}}$ receptors were labeled with $0.1 \mathrm{nM}$ $\left[{ }^{3} \mathrm{H}\right]-8-\mathrm{OH}-\mathrm{DPAT}$. The nonspecific binding was determined by using 8-OH-DPAT. Various concentrations of the compound to be tested were used and incubated with the tissues and $\left[{ }^{3} \mathrm{H}\right\}-8-\mathrm{OH}-\mathrm{DPAT}$ for $20 \mathrm{~min}$ at $37^{\circ} \mathrm{C}$. Samples were filtered over glass filters. The individual filters were poured into vials and equilibrated with $5 \mathrm{~mL}$ of scintillation fluid then counted at $45 \%$ efficiency in Beckman 3801 counter. Computer program EBDA was used to analyze the data and to determine $\mathrm{K}_{\mathrm{i}}$.

\section{ACKNOWLEDGEMENT}

The author wishes to thank Professor Richard A. Glennon for his support and valuable guidance. Thanks also are due to Prof. M. Teitler for the radioligand binding assays.

\section{REFERENCES}

(1) Vialli, M.; Erspamer, V., Ztschr Zellforsch U Mika Anat., 19: 732 (1933)

(2) Rapport, M.M.; Green, A.A., Page, I.H.; Fed. Proc. 6: 184 (1947).

(3) Gaddum, J.H.; Picarelli, Z.P., Br. J. Pharmacol., 12: 323 (1957). 
(4) Peroutka, S.J.; Snyder, S.H., Mol, Pharmacol., 14: 687 (1979).

(5) Schnellman, R.G.; Waters, S.J., Nelson, D.L., J. Neurochem. 42 : 65 (1984).

(6) a. Glennon, R.A.; Westkaemper, R.B.; Bartyzel, P.; In: Serotonin Receptor Subtypes; ed. Peroutka, S.J., Wiley-Liss, NY pp. 19-24 (1991).

b. Schmidt, A.W.; Peroutka, S.J., FASEB. J.,3: 2242 (1989).

c. Ford, A.P.; Clak, D.E., Med. Res. Rev, 13 (6), 633 (1993).

(7) Bradley, P.B.; Engel, G.; Feniuk, W., Neuropharmacol., 25: 563 (1986).

(8) Dumuis, A.; Bouhelal, R.; Sebben, M.; Cory, R.; Bockaert, J. Mol. Pharmacol., 34: 880 (1988).

(9) El-Mestikawy, S.; Fargin, A.; Raymond, J.R.; Gozlan, H.; Hanatowich, M., Neurochem. Res., 16: 1 (1991).

(10) Glennon, R.A., In: Advances in CNS Drug-Receptor Interaction, ed. Cannon, J. G., Vol. 1, JAI Press, Greenwich, CT. pp. 131 (1991).

(11) Traber, J.; Glaser, T., Trends Pharmacol. Sci., 8: 432 (1987).

(12) Glennon, R.A., Durg. Dev. Res., 26: 251 (1992).

(13) Fozard, J., Trends Pharmacol, Sci., 8: 501 (1987).

(14) Glennon, R.A., J. Med. Chem., 30: 1 (1987).

(15) Glennon, R.A., Naiman, N.A., Lyon, R.A., Teitler, M., J. Med. Chem., 31: 1968 (1988).

(16) Raghupathi, R.K., Rydelek-Fitzgerald, L., Teitler, M., Glennon, R.A., J. Med, Chem., 34: 2633 (1991).

(17) Titeler, M., Lyon, R.A., Davis, K.H., Glennon, R.A., Biochem. Pharmacol., 36: 3265 (1987). 
M. A. El-Bermawy

(18) Abou-Gharbia, M.; Patel, U.R.; Webb, M.B.; Moyer, J.A.; Andre, T.H.; Muth, E.A., J.Med. Chem., $31: 1382$ (1988).

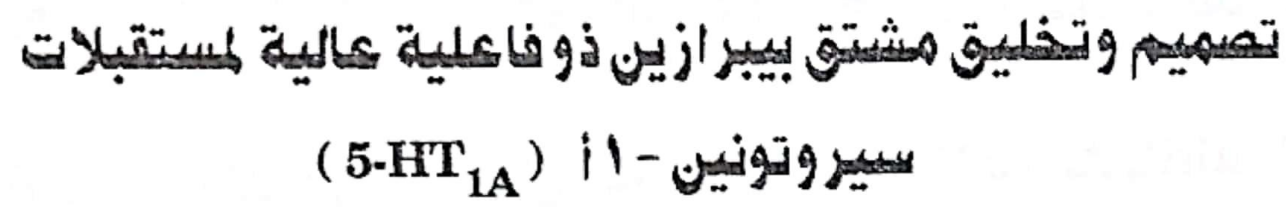

ماسعد عبد الثافى البرماوى

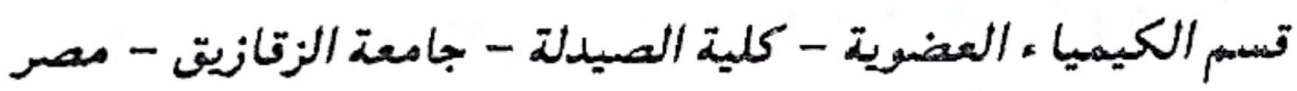

ثبت أن مستقبلات السبروتونين م-HT

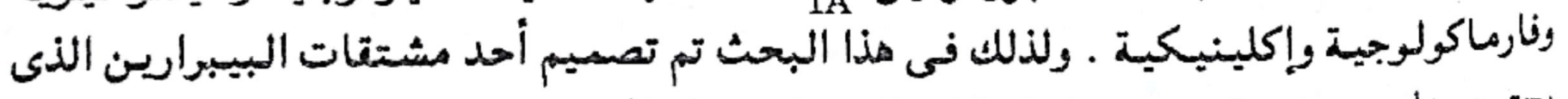

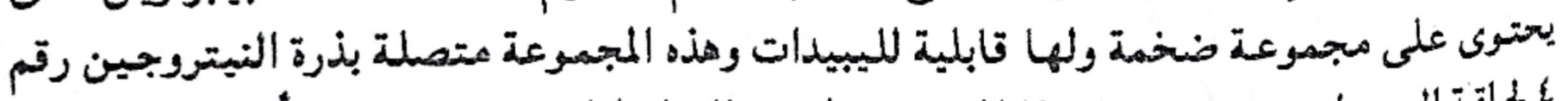

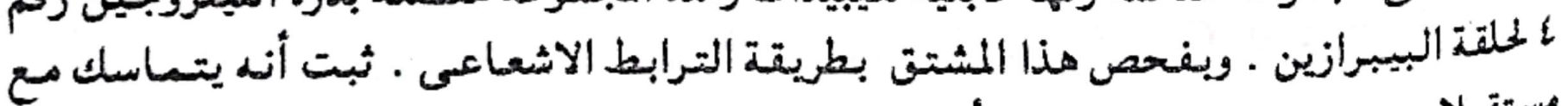

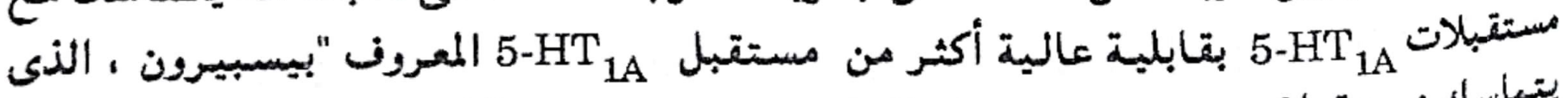

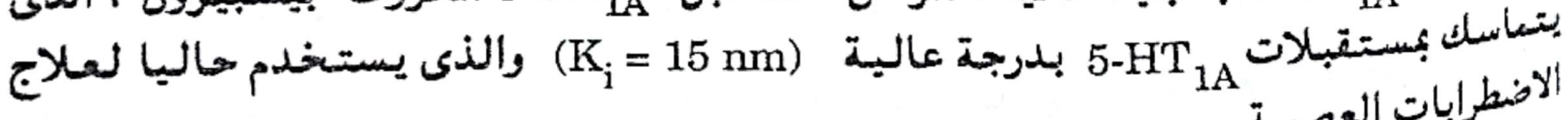
الاضطرابات العصبية. 